\title{
Malignant mixed germ cell tumor of ovary: a rare case report
}

\author{
Bhawana Tiwary ${ }^{1}$, Hemali Heidi Sinha ${ }^{1}$, Vivek K. Pandey ${ }^{2}$
}

\author{
${ }^{1}$ Department of Obstetrics \& Gynaecology, AIIMS, Phulwarisharif, Patna, Bihar, India \\ ${ }^{2}$ Department of Pathology, Darbhanga Medical College, Darbhanga, Bihar, India
}

Received: 15 February 2015

Accepted: 01 March 2015

\author{
*Correspondence: \\ Dr. Bhawana Tiwary, \\ E-mail: bhawana.tiwary@gmail.com
}

Copyright: (C) the author(s), publisher and licensee Medip Academy. This is an open-access article distributed under the terms of the Creative Commons Attribution Non-Commercial License, which permits unrestricted non-commercial use, distribution, and reproduction in any medium, provided the original work is properly cited.

\begin{abstract}
Ovarian germ cell tumors are very rare and affect mainly young girls and women. One of the most remarkable advances in oncology is in the treatment of malignant ovarian germ cell tumors. The two histological groups are: dysgerminomas and non dysgerminomatous tumors. We report a case of a 29 years old multiparous woman who presented with persistent pain abdomen and was diagnosed to have a malignant mixed germ cell tumor comprising of both dysgerminoma and yolk sac tumor (endodermal sinus tumor).
\end{abstract}

Keywords: Malignant mixed germ cell tumor, Dysgerminoma, Yolk sac tumor, Endodermal sinus tumor

\section{INTRODUCTION}

Ovarian germ cell tumors comprise approximately $15 \%$ to $20 \%$ of all ovarian neoplasms. Malignant germ cell tumors comprise less than $5 \%$ of all ovarian neoplasms. The incidence of malignant ovarian germ cell tumors range from 1 to 6 percent in the West and from 8 to 19 percent in Asia. ${ }^{1}$

The diagnosis suspected on physical examination, relies on pelvic or transvaginal ultrasonographic detection of an ovarian mass causing abdominal discomfort or lump. However, this is confirmed only after surgical intervention. Tumor markers such as Human Chorionic Gonadotropin (HCG), and alpha-fetoprotein also contribute to the diagnosis, prognosis and follow up of the disease.

We present a case of malignant mixed germ cell tumor comprising of dysgerminoma and yolk sac tumor.

\section{CASE REPORT}

A 29 years old multiparous woman presented with a complaint of persistent pain abdomen, localized to bilateral iliac fossae with no radiation since 2 months. There was no complain of menstrual irregularities. With this complain the patient consulted a private obstetrician. There was no family history of gynaecological malignancies. An ultrasound pelvis was done which was suggestive of bulky uterus with multiple intramural and subserous fibroids, largest being $6.3 \times 6.8 \mathrm{~cm}$ and bilateral ovaries were reported to be normal. With this ultrasound report the patient visited the gynaecology outpatient department of AIIMS Patna.

Physical examination revealed that she had mild pallor and she was afebrile. Vital signs were as follows: blood pressure of 100/60 $\mathrm{mm}$ of $\mathrm{Hg}$, pulse rate of $70 \mathrm{bpm}$ and respiration of $18 / \mathrm{min}$. She had a distended abdomen with a firm, palpable mass in the hypogastrium of about 18 week size with restricted mobility. There was no tenderness, guarding or rigidity. On speculum examination, the cervix and vagina revealed no abnormality. There was nodularity or deposit seen. On bimanual examination, a firm to hard mass of 18 week size was palpable in pouch of Douglas deviated more on right side. Rectal mucosa was free. With these findings, the patient was subjected to a repeat ultrasound at our institute which revealed a large lobulated solid mass in 
right adnexa $15.9 \times 14.3 \times 11.5 \mathrm{~cm}$ with cystic areas and focal calcifications. Left ovary was normal. Uterus measured $11 \times 3 \mathrm{~cm}$, deviated to left. It also showed an enlarged lymph node of 4.6 x $4.2 \mathrm{~cm}$ along right iliac vessels. She also underwent a CT scan of abdomen and pelvis which showed a large solid enhancing soft tissue density mass lesion of about 13 x $15 \mathrm{~cm}$ seen in abdominopelvic region predominantly on right side inseparable from right ovary. Multiple enlarged retroperitoneal lymph nodes with mild ascites were found.

Initial laboratory results revealed a normal complete blood count, electrolytes, blood urea, creatinine and glucose. We also ordered the tumor markers which were as follows: CA-125: $526 \mathrm{U} / \mathrm{ml}, \mathrm{HCG}: 135 \mathrm{mIU} / \mathrm{ml}$, Alfafetoprotein: $1.79 \mathrm{ng} / \mathrm{ml}$. Chest X-ray was normal and Pap smear was negative for intraepithelial lesion or malignancy.

Patient underwent exploratory laparotomy at AIIMS Patna. Intra-operatively, $200 \mathrm{ml}$ of ascetic fluid was present. An ovarian tumor $20 \times 15 \mathrm{~cm}$ was seen arising from right ovary adherent with appendix with a ruptured capsule. Left ovary had a small metastatic deposit. Total abdominal hysterectomy with bilateral salpingooophorectomy was done along with appendicectomy and omentectomy. A 4 × $3 \mathrm{~cm}$ metastatic deposit was present in pouch of Douglas. A para-aortic lymph node $5 \times 4 \mathrm{~cm}$ was present which was excised. Hence, a post-operative diagnosis of malignant right ovarian tumor stage III C was made.

On gross pathologic examination, sections through the ovary showed a very haemorrhagic and necrotic tumor. Microscopic specimens determined the tumor to be a germ cell tumor with dysgerminoma and yolk sac tumor elements. Para-aortic lymph node was also involved with tumor with areas of haemorrhage and necrosis.

The patient had a usual post-operative course apart from 4 units of packed cell transfusion and has been planned for 4 cycles of chemotherapy with BEP (Bleomycin, etoposide and cisplatin) regimen.

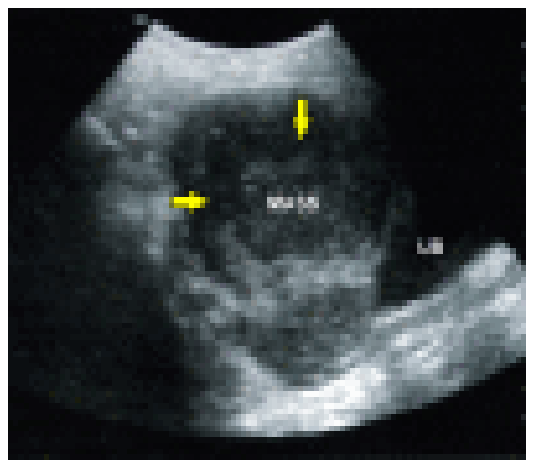

Figure 1: Ultrasound examination revealed a mass of mixed echogenicity in the right adnexa (arrows). UB = Urinary bladder.

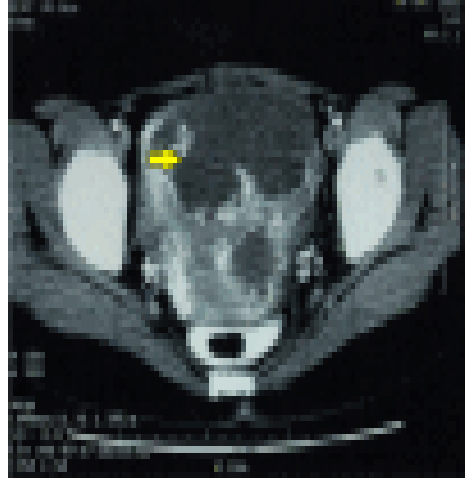

Figure 2: Computed tomography scan of the pelvis revealed a highly vascular enhancing mass (arrow) in the pelvis.

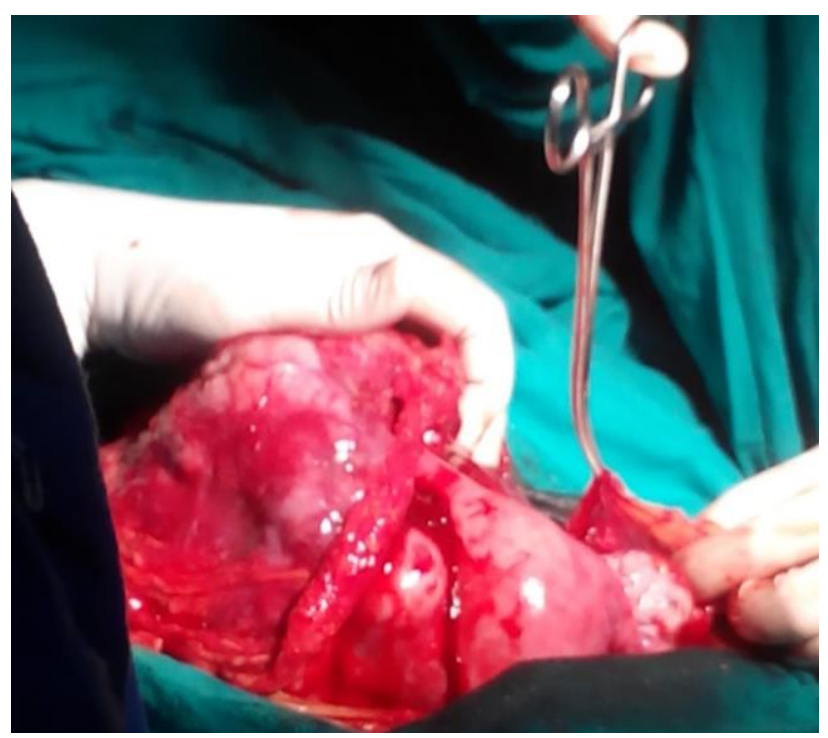

Figure 3: Intraoperative findings showing uterus with massive right sided adnexal mass.

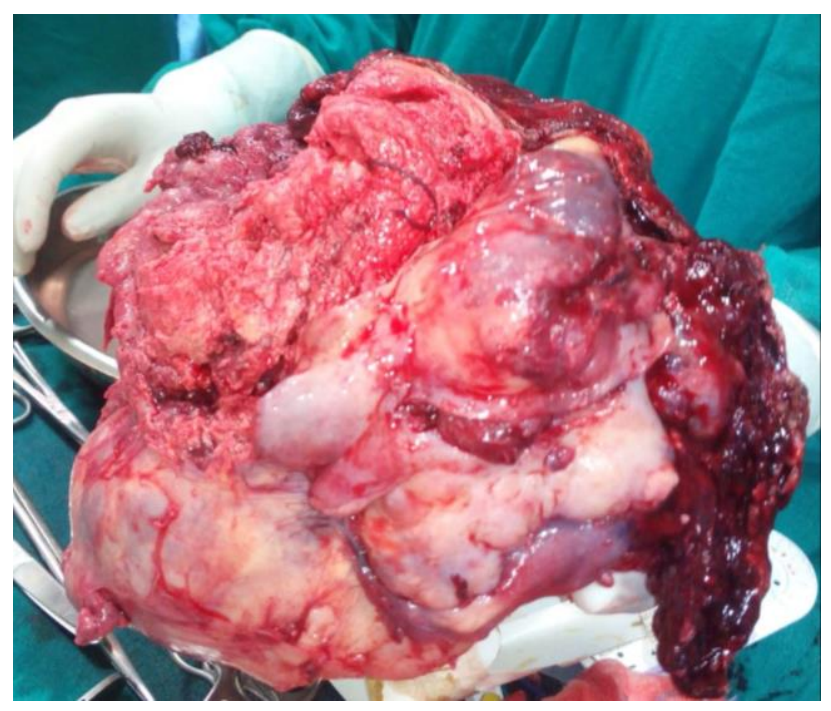

Figure 4: Gross specimen of ovarian tumor after debulking. 


\section{DISCUSSION}

Ovarian germ cell neoplasms are thought to be derived from primitive germ cells of the embryonic gonad. They constitute the second largest group accounting for 15 to 20 percent of all ovarian neoplasms. Malignant germ cell tumors comprise less than 5 percent of all ovarian neoplasms. ${ }^{2}$ In 1973, the World Health Organization classified germ cell tumors as dysgerminoma, yolk sac tumor, embryonal carcinoma, polyembryoma, choriocarcinoma, teratomas, mixed and gonadoblastoma. ${ }^{3}$ This initiative represented a major advance in terms of standardization of nomenclature and histological criteria.

These tumors can occur in women at any age, but peak incidence is seen during the early 20 's. In children and adolescents, more than $60 \%$ of ovarian neoplasms are of germ cell origin, of which approximately $1 / 3$ are malignant. Dysgerminoma is the most common germ cell tumor, accounting for $50 \%$ of all germ cell tumor cases. The yolk sac tumor (also known as endodermal sinus tumor) is the second most common germ cell tumor, accounting for $20 \%$ of all cases, and is common in girls and young adults with an average age of 19 years. Less common tumors are embryonal carcinoma, immature teratoma, choriocarcinoma, polyembryomas, and mixed germ cell tumors.

Mixed germ cell tumors of ovary contain two or more elements of the lesions described above. In our case the combination was that of dysgerminoma and yolk sac tumor. The mixed lesions may secrete either HCG, Alfafetoprotein or both or neither of these markers, depending on the components. The most important prognostic features are the size of the primary tumor and the relative size of its most malignant component.

Clinically, a substantial majority of patients with germ cell tumors present with abdominal pain, abdominal distension or a pelvic mass. Approximately 10 percent of patients will present with acute abdominal pain, usually caused by rupture, haemorrhage, or torsion of the ovarian mass.

Both HCG and alpha-fetoprotein are secreted by some germ cell malignancies, therefore the presence of circulating hormones may prove to be useful in the diagnosis and in monitoring the response to treatment. ${ }^{4,5}$ Ultrasonography or CT is helpful in delineating the size and complexity of these tumors. Preoperative staging is possible with CT. ${ }^{1}$

Microscopically, a dysgerminoma component is present in 80 percent, endodermal sinus tumor in 70 percent, immature teratoma in 53 percent, choriocarcinoma in 20 percent and embryonal carcinoma in 16 percent. Mixture of dysgerminoma and endodermal sinus tumor is most common combination, accounting for $1 / 3^{\text {rd }}$ of cases. ${ }^{6}$

Treatment consists of salpingo-oophorectomy with adjunctive chemotherapy. Chemotherapeutic regimens have evolved to combination therapy with overall disease free survival rates of greater than 95 percent $^{3}$. In view of malignant germ cell tumors occurring almost exclusively in young females, preservation of their ovarian function and fertility is becoming an important, although controversial issue in gynaecologic oncology. A study by Zanetta et al. confirmed that normal gonadal function and fertility are possible after conservative surgery for ovarian germ cell malignancies, even with adjuvant chemotherapy. ${ }^{7}$ In our case we went for complete staging laparotomy and tumor debulking as she had her family completed. Tumors composed of less than one-third endodermal sinus tumor, choriocarcinoma, or grade 3 immature teratoma have an excellent prognosis, but it is less favorable when these components constitute most of the mixed lesions. ${ }^{2}$

Funding: No funding sources

Conflict of interest: None declared

Ethical approval: Not required

\section{REFERENCES}

1. Lim FK, Chanrachakul B, Chong SM, Ratnam SS. Malignant ovarian germ cell tumours: experience in the national university of hospital of Singapore. Ann Acad Med Singapore. 1998;27(5):657-61.

2. Gershenson DM, Del Junco G, Copeland LJ, Rutledge FN. Mixed germ cell tumors of the ovary. Obstet Gynecol. 1984;64(2):200-6.

3. Gershenson DM. Update on malignant ovarian germ cell tumors. Cancer. 1993;71(4 Suppl):1581-90.

4. Kurman RJ, Norris HJ. Malignant germ cell tumors of the ovary. Hum Pathol. 1977;8(5):551-64.

5. Berek JS, Adashi EY, Hillard PA. HCG and Alphafetoprotein. In: Berek JS, Adashi EY, Hillard PA, eds. Novak's Gynecology. 12th ed. Baltimore: Williams \& Wilkins; 1996.

6. Kurman RJ, Norris HJ. Embryonal carcinoma of the ovary: a clinicopathologic entity distinct from endodermal sinus tumour resembling embryonal carcinoma of adult testis. Cancer. 1976;38(6):242033.

7. Zanetta G, Bonazzi C, Cantu M, Binidagger S, Locatelli A, Bratina G, et al. Survival and reproductive function after treatment of malignant germ cell ovarian tumors. J Clin Oncol. 2001;19(4):1015-20.

DOI: 10.5455/2320-1770.ijrcog20150450

Cite this article as: Tiwary B, Sinha HH, Pandey

VK. Malignant mixed germ cell tumor of ovary: a rare case report. Int J Reprod Contracept Obstet Gynecol 2015;4:511-3. 